\title{
Functional role of polyphenol rich butanol fraction of Rivea ornata in experimentally induced myocardial infarction: Preservation of Cell viability and Free radical neutralization
}

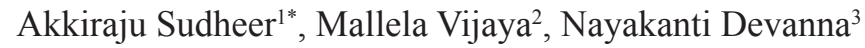 \\ ${ }^{1}$ Department of Pharmaceutical science, Jawaharlal Nehru Technological University Aanantapur, Ananthapuramu, India. \\ ${ }^{2}$ Department of Pharmaceutical Chemistry, Raghavendra Institute of Pharmaceutical Education and Research (RIPER), Ananthapuramu, India. \\ ${ }^{3}$ Department of Chemistry, Jawaharlal Nehru Technological University Anantapur, Ananthapuramu, India.
}

\section{ARTICLE INFO \\ Received on: $14 / 11 / 2020$ \\ Accepted on: 09/01/2021 \\ Available online: 05/06/2021}

\section{Key words:}

Rivea ornata, butanol

fraction, isoproterenol,

ATPases, oxidative stress,

inflammation markers.

\begin{abstract}
The main motto of the current in vivo study was to understand the role of polyphenolic butanol fraction of Rivea ornata in rodent model of myocardial infarction (MI). Polyphenolic fraction separated from crude ethanol extract in to butanol fraction by solvent/solvent fractionation from nonpolar to polar. Male wistar rats $(n=30)$ were assigned as control, isoproterenol (ISO), carvedilol, butanol fraction $(200,400 \mathrm{mg} / \mathrm{kg}$, p.o.) groups. At the end of pretreatment, ISO is injected in two days to all groups except control to cause MI. Observations like Electrocardiogram, infarction markers (Lactate dehydrogenase, Creatine kinase-MB, C-reactive protein), Sodium-potassium adenosine triphosphatase and Calcium adenosine triphosphatase, oxidative stress markers [Catalase (CAT), Superoxide dismutase (SOD), Reduced glutathione (GSH) \& Malondialdehyde (MDA)], inflammation markers Tumour Necrosis Factor alpha (TNF- $\alpha$ ), Interleukins (IL-6 \& 10) and histopathological examinations were performed in all groups. ISO induced changes like ST segment elevation, elevation of serum infarction markers, reduced membrane bound adenosine triphosphatases, reduced levels of CAT, SOD, GSH \& higher MDA content, higher inflammation markers (TNF- $\alpha$ and IL-6) myocardial damage were positively restored by butanol fraction especially at $400 \mathrm{mg} / \mathrm{kg}$. Hence, cardioprotective effect was could be due to its antioxidant, cardiac membrane stabilization, anti-inflammatory action.
\end{abstract}

\section{INTRODUCTION}

Interruption of coronary blood flow partially or completely to a portion of the myocardium over the threshold result in to infraction. According to statement given by World Health Organization (WHO), highest mortality rate is accounted by the ischemic heart diseases (Aronow, 2006; Patel et al., 2010). Despite modern medicines are widely used to treat cardiovascular diseases but its cost, side effects, availability, people are looking in to traditional and complementary medicines has been increased to preventive medicine of human diseases (Adenipekun et al., 2018). Bioactive phytochemicals such as polyphenols, flavonoids, tannins, anthocyanins rich fruits, vegetable,

\footnotetext{
"Corresponding Author

Akkiraju Sudheer, Department of Pharmaceutical science, Jawaharlal Nehru Technological University Aanantapur, Ananthapuramu, India. E-mail: sudeerlegend@gmail.com
}

medicinal plants and its extracts have been shown to beneficial in treating in heart disorders (ischemic heart disease, cardiac arrythmias, heart failure) and vascular problems (atherosclerosis, endothelial dysfunction, hypertension) (Ganapathy et al., 2020). Underlined cardioprotective mechanism involved is improving contractile function of heart, attenuation of Low-density lipoprotein oxidation, preservation of membrane bound ATPases, regulating calcium load, nitric oxide availability, mitochondrial dysfunction, myocardial inflammation (Li et al., 2016). Even several natural products rich in flavonoids, polyphenolics and its isolated compounds such as luteolin, apigenin, gallic acid, maslinic acid, rosmarinic acid, ellagic acid etc., are reported to antagonize the isoproterenol (ISO) induced oxidative stress in myocardium due to its antioxidant activity (Mohan et al., 2010). Hence discovery of novel phytochemicals having antioxidant activity are advantages in oxidative stress induced myocardial infraction (Panda, 2015). Preclinical, clinical trials and epidemiological studies highlight the pivotal role antioxidants 
in preventing of heart diseases (Brewer, 2011; Speer et al., 2020). Folk medicines are practiced in various indigenous cultures around the world even though the advancement of allopathic medicines happened with advanced technology and science (Thomford et al., 2018). Therefore, WHO has taken into account and established traditional medicine strategy plan for 2023 to address the issues and promote safe, effective and quality traditional medicines around the globe. India has been practising the diversified health care system which includes Allopathy, Ayurveda, Unani, Siddha and Homeopathy to deliver the possible best health care to the society. Keeping this in view India established Ministry of Ayurveda, Yoga \& Naturopathy, Unani, Siddha and Homoeopathy to set standard regulations for herbal drugs and also included the herbal medicines in Indian pharmacopeia and essential drug list (Shankar and Patwardhan, 2017) Rivea ornata is a climber with cylindrical stem, broader leaves, white silky flowered and smooth surface subglobose brown colored fruits. Literature mentions its traditional importance in treating disorder of gallbladder, disease of heart, bronchitis, and fatigue. In the Konkan, its juice is used to treat piles (Kirtikar and Basu, 1918). Therefore, we try to create scientific evidence for its protective capacity by rodent model myocardial infarction (MI).

\section{MATERIALS AND METHODS}

\section{Chemicals and equipment's}

ISO, Folin-Ciocalteu reagent, 2,2-diphenyl-1picrylhydrazyl, vitamin $\mathrm{C}$, aluminium chloride were purchased from Sigma chemicals. Gallic acid, Quercetin (TCI chemicals, India Pvt. Ltd. Chennai Tamilnadu), Ethylenediaminetetraacetic acid (EDTA), Trichloroacetic acid (TCA), 5,5 dithiobis 2-nitro benzoic acid (DTNB) Thiobarbituric acid (TBA) were purchased from Loba chemie Pvt. Ltd. Carvedilol gift sample from Connexions life sciences, Bangalore. Thin Layer Chromatography (TLC) precoated silica gel 60 plates (Merck), Silica gel (230-400 Mesh) from Thermo fisher scientific India Pvt.Ltd. MP30 data acquisition system (BIOPAC, Santa Barbara, CA) Rota evaporator (Aditya scientific, Hyderabad, Telangana), UV visible spectrophotometry (Labindia UV 3000), Semi-autoanylser (ERBA CHEM 7), ELISA kits (Rey biotech kits) and Cooling centrifuge (Remi).

\section{Collection and identification of the plant material}

Fresh leaves collected from flowering plant of $R$. ornata, were collected from Tirumala hills during between December to January and dried under shade. The plant was authenticated by Prof. K. Madhava Chetty, Taxonomist, and a voucher specimen (voucher number:0913) has been stored at S.V. University (Botany department) Tirupati, (A.P, India).

\section{Preparation of extract}

$1 \mathrm{~kg}$ of dried leaves powder was macerated with 3 1 of ethanol $(99 \%)$ for 1 week. Filtrate gets concentrate using rota-evaporator, followed by drying to get the concentrate form (Senguttuvan et al., 2014).

\section{Solvent/solvent fraction of ethanol extract of $\mathbf{R}$. ornata}

Hot water dissolved ethanol extract was fractionated by solvents from nonpolar to polar (n-hexane (non-polar), ethyl acetate (medium polar) and n-butanol (low polar)) respectively. After that, each fraction was concentrated using rotary evaporator. Finally, they tested for presence of flavonoids and other phytochemicals using coloration reactions reported in standard reference books and assessed the flavonoid and phenolic content (Stalikas, 2007).

\section{Identification of flavonoids by TLC}

$\mathrm{n}$-Butanol fraction was tested in TLC for presence of flavonoids. Butanol fraction loaded pre-coated silica gel TLC plate was kept in closed pre-saturated chamber for 30 minutes. In the TLC method, n-hexane and ethylacetate (1:1) was used as optimized mobile phase in order to effective separation. After development of TLC chromatogram of butanol extract and standard flavonoid, plates had been removed and dried, the spots were visualized by kept in and iodine chamber (Saeed et al., 2012).

\section{Separation of n-butanol fraction}

Methanol solubilized butanol fraction ( $2 \mathrm{~g}$ ) was mixed with silica gel in motor by trituration with pestle. Fraction coated silica gel placed on the top of silica gel (60-120 mesh) packed chromatography column $(75 \times 3.5 \mathrm{~cm})$. The column was serially eluted with hexane, hexane and ethyl acetate (1:1 ration) and ethyl acetate. Total 40 sub-fractions were collected and those fractions TLC matching with standard flavonoid (quercetin) are mixed together (Etame et al., 2019).

\section{Acute toxicity studies}

It was performed as per specification of Organisation for Economic Co-operation and Development, 423 protocol. No toxic symptoms or mortality was observed until the 14 days of the period with butanol extract of $R$. ornata $2,000 \mathrm{mg} / \mathrm{kg}$ bw. Hence, further experimental dose was selected as one tenth and one fifth of the $\mathrm{LD}_{50}$ dose that is 200 and $400 \mathrm{mg} / \mathrm{kg}$ (Maithili et al., 2011).

\section{Animals}

The IAEC of RIPER, Anantapur has approved our protocol [878/ac/05/Committee for the Purpose of Control And Supervision of Experiments on Animals (CPCSEA)/005/2016] as per guidelines of CPCSEA, Govt of India, New Delhi.

\section{Experimental design}

Albino Wistar rats allotted as follows with minimum number $(n=6)$. Group 1 (Normal rats): no specific treatment, Group 2 (ISO control rats): received vehicle only (38), Group 3: Carvedilol (2 mg/kg, B.W, p.o.) (Shahzad et al., 2019), Group 4 \& 5: received butanol fractions (200 and $400 \mathrm{mg} / \mathrm{kg}$, B.W, p.o.). MI was induced to all groups (in last two days) except group 1 by ISO injection $(100 \mathrm{mg} / \mathrm{kg}, \mathrm{sc})$.

\section{Electrocardiogram (ECG)}

Under the anesthesia (ketamine, $80 \mathrm{mg} \mathrm{kg}$ I.P and xylazine, $8 \mathrm{mg} / \mathrm{kg}$ IP), ECG was recorded with lead II position by digital physiograph (BIOPAC, Santa Barbara, CA) (Zhu et al., 2019).

\section{Biochemical screening}

On the 31st day, the blood samples [not more than $1 \%$ total body weight (B.W)] were withdrawn by non-terminal procedures (retro-orbital plexus) and clotted blood samples were 
centrifuged (2,500 rpm, 20 minutes) (Parasuraman et al., 2010; Upaganlawar et al., 2009). On the same day we analyzed it for quantitative estimation of Creatine kinase-MB (CK-MB), Lactate dehydrogenase (LDH), C-reactive protein (C-RP) by using semiautoanylser ERBA CHEM (Manjunatha et al., 2020).

\section{Estimation of myocardial tissue parameters}

Myocardial tissue was separated from all animals (sacrificed by pentobarbitone injection at dose $60 \mathrm{mg} / \mathrm{kg}$, i.p) and prepared and stored $10 \% \mathrm{w} / v$ homogenate in ice cold $0.1 \mathrm{M}$ Tris-HCL buffer ( $\mathrm{pH}$ 7.4). Homogenate used for estimation of the followings.

\section{Superoxide dismutase (SOD)}

It was estimated according to protocol by Misra and Fridovich (1972). Briefly described, reaction mixer was prepared by combining supernatant of tissue homogenate $(0.5 \mathrm{ml}), 0.05 \mathrm{M}$ carbonate buffer $(1.5 \mathrm{ml}, \mathrm{pH} 10.2)$ and EDTA $(0.5 \mathrm{ml})$ in a test tube. To this $0.5 \mathrm{ml}$ of epinephrine $(3 \mathrm{mM})$ was added and changes in absorbance was recorded for 3 minutes with 30 seconds interval at $480 \mathrm{~nm}$. Its quantity was expressed as units/ $\mathrm{mg}$ of protein (Misra and Fridovich, 1972).

\section{Catalase (CAT)}

It was estimated according to protocol of Aebi (1984). Briefly described, in a clean test tube we taken $2 \mathrm{ml}$ of Diluted tissue homogenate and $1 \mathrm{ml}$ of $50 \mathrm{~m} \mathrm{~mol} / \mathrm{l}$ phosphate buffer $(\mathrm{pH}$ 7). To this, $1,000 \mu \mathrm{l}$ of $\mathrm{H}_{2} \mathrm{O}_{2}(30 \mathrm{n} \mathrm{mol} / \mathrm{l})$ just added before taking optical density at $240 \mathrm{~nm}$; taken the readings for 3 minutes with 15 seconds interval. Its quantity expressed as $\mu \mathrm{mol}$ of $\mathrm{H}_{2} \mathrm{O}_{2}$ evolved/ mg of protein.

\section{Reduced glutathione (GSH)}

It is estimated as per protocol of Moron et al. (1979). Briefly described, in a test tube tissue homogenate $(1 \mathrm{ml}), 10 \%$ $w / v$ TCA $(1 \mathrm{ml})$ were taken and kept at $60^{\circ} \mathrm{C}$ for 20 minutes on water bath and then centrifuged (at 2,000 rpm for 15 minutes). Supernatant $(0.5 \mathrm{ml})$, DTNB $(4 \mathrm{ml})$ and $0.2 \mathrm{M}$ phosphate buffer at $\mathrm{pH} 8.0(1.5 \mathrm{ml})$ mixed together in a test tube. The absorbance of developed yellow color solution was read against the blank at 412 $\mathrm{nm}$ using spectrophotometer and its quantity was noted as $\mu \mathrm{g}$ of $\mathrm{GSH} / \mathrm{mg}$ of protein (Moron et al., 1979).

\section{Malondialdehyde (MDA)}

It was estimated by the protocol of Slater and Sawyer (1971). As per procedure, we added $2 \mathrm{ml}$ of homogenate, $2 \mathrm{ml}$ of TCA $(20 \% \mathrm{w} / \mathrm{v})$ in a test tube and incubate at $60^{\circ} \mathrm{C}$ for 20 minutes and then cool for 15 minutes. From the centrifuged (3,000 rpm, 15 minutes) mixture, $2 \mathrm{ml}$ of supernatant was taken and added with $2 \mathrm{ml}$ of TBA $(0.67 \% \mathrm{w} / \mathrm{v}$ in Tris hydrochloride, $\mathrm{pH} 7)$ again it was incubated at $60^{\circ} \mathrm{C}$ (10 minutes). Developed pink colored solution absorbance was noted against blank at $535 \mathrm{~nm}$ using spectrophotometer. Units are expressed as $\mathrm{nm}$ of $\mathrm{MDA} / \mathrm{gm}$ of tissue (Slater and Sawyer, 1971).

\section{Estimation of other biochemical parameters}

Cardiac tissue Sodium-potassium adenosine triphosphatase $\left(\mathrm{Na}^{+} \mathrm{K}^{+}\right.$ATPase), Calcium adenosine triphosphatase
$\left(\mathrm{Ca}^{2+}\right.$ ATPase) (Al-Numair et al., 2015), calcium (0 - cresolphthalein complexone method), sodium (trinder method) potassium (tetra phenyl borate method) and protein (Lowry et al., 1951) contents were estimated by Erba semi-auto analyser kits (Upaganlawar and Balaraman, 2011).

\section{Estimation of inflammation markers}

Cardiac inflammatory mediators Tumour Necrosis Factor alpha (TNF- $\alpha$ ), Interleukins (IL-6 \& 10) were quantified as per instruction given by the standard ELISA kits (Rey biotech kits) (Shahzada et al., 2018).

\section{Histopathology}

Some excised hearts were fixed in fixing solution $(10 \%$ buffered formalin) and processed for histopathological sections and then stained with haematoxylin and eosin.

\section{Statistical analysis}

The data generated in our study was analyzed by oneway analysis of variance followed by the Bonferroni multiple comparisons test with help of Prism, Graph pad software. We considered values were significant when $p$ is less than 0.05 .

\section{RESULTS AND DISCUSSION}

\section{Preliminary qualitative phytochemical analysis}

Active constitutes of the plant or its crude drugs are known to be responsible for their pharmacological actions. Among polyphenolic compounds such as flavonoids, stilbenes, lignans tannins are naturally occurring diverse phytochemicals available in fruits, leaves, seeds (Mondal et al., 2019). Various epidemiological studies revealed its therapeutic role in cardiovascular diseases, diabetes, cancers, neurodegenerative diseases. So, there is a much attention has been increasing to take polyphenolic rich plants or its extracts in the context of current scenario (Cory et al., 2018). These compounds attain more in polar solvents like butanol (Rita et al., 2016). Hence, observations of preliminary qualitative study have validated the presence of flavonoids and tannins in butanol fraction rather than other solvents. (Sharma and Janmeda, 2017) The results are shown in Table 1.

\section{Qualitative tests for presence of flavonoids in butanol fraction}

Butanol fraction of $R$. ornata showed with positive evidence for flavonoids by major flavonoids test compared to other fractions. The results of this found in Table 2. Literature stated that flavonoids rich extracts have beneficial effect in oxidative stress induced myocardial injury and these may be used as adjuvant in the stopping or prevention of development of cardiovascular diseases. (Auwal et al., 2014)

\section{Quantification of contents of R. ornata extracts and its fraction (phenolic and flavonoid)}

The above said contents were derived from gallic acid and quercetin calibration curves. Butanol fraction has shown highest phenolic and flavonoid contents $(82.4 \pm 4.61 \mathrm{mg}$ of Gallic acid equivalents $/ \mathrm{g}, 105 \pm 4.09 \mathrm{mg}$ of quercetin/g) compared to crude ethanol and its other fractions. Antioxidant potency is mainly depending on its phenolic and flavonoids content, being capable 
Table 1. Phytochemical composition of extracts of R. ornata.

\begin{tabular}{clccccc}
\hline S. No & Test for & Crude ethanol extract & Hexane fraction & Ethyl acetate fraction & Butanol fraction & Aqueous fraction \\
\hline 1. & Carbohydrates & + & - & + & + & + \\
2. & Steroids & + & + & + & + & + \\
3. & Cardiac glycosides & + & - & - & - & - \\
4. & Saponin glycosides & - & - & + & - & - \\
5. & Coumarins & - & - & + & + & - \\
6. & Flavonoids & + & - & - & + & + \\
7. & Alkaloids & + & - & - & - & - \\
8. & Tannins & + & + & - & - & - \\
9. & Terpenoids & - & - & & - \\
10. & Anthraquinone glycosides & - & & & - & - \\
\hline
\end{tabular}

Table 2. Qualitative results of flavonoids in $R$. ornata plant extracts

\begin{tabular}{|c|c|c|c|c|}
\hline Extract & $\begin{array}{c}\text { Shinoda test } \\
\text { (deep red colour) }\end{array}$ & $\begin{array}{l}\text { Lead acetate test } \\
\text { (yellow colour ppt) }\end{array}$ & $\begin{array}{c}\text { Pews tests } \\
\text { (red colour to cherry red colour) }\end{array}$ & $\mathrm{NaOH}$ (yellow colour) \\
\hline Crude ethanol extract & + & + & + & + \\
\hline $\mathrm{n}$-Hexane fraction & - & - & - & - \\
\hline Ethyl acetate fraction & - & + & + & + \\
\hline Butanol fraction & + & + & + & + \\
\hline Aqueous fraction & - & - & - & - \\
\hline
\end{tabular}

Table 3. Total phenolic and total flavonoid content of ethanol and its fractions of $R$. ornate.

\begin{tabular}{lcc}
\hline Extract & TPC $(\mathbf{m g}$ of gallic acid equivalent $/ \mathbf{g})$ & TFC $(\mathbf{m g}$ of quercetin equivalent/g) \\
\hline Crude ethanol extract & $56.9 \pm 4.30$ & $55.1 \pm 2.79$ \\
n-Hexane fraction & $6.39 \pm 1.38^{* * *}$ & $16.7 \pm 0.351^{* * *}$ \\
Ethyl acetate fraction & $64.2 \pm 1.56$ & $77.5 \pm 6.20^{*}$ \\
Butanol fraction & $82.4 \pm 4.61^{* *}$ & $105 \pm 4.09^{* * *}$ \\
Aqueous fraction & $18.1 \pm 3.52^{* * *}$ & $27.7 \pm 4.10^{* *}$ \\
\hline
\end{tabular}

Represented mean \pm standard error mean (SEM) values $(N=3)$ considered as significant when $\mathrm{p}$ values less than 0.05 and $p$ values are marked as follows.

$P$ values are marked as follows i.e., ${ }^{*} p<0.05 ;{ }^{*} p<0.01 ; * * *<0.001$.

of donating hydrogens to highly unstable free radicals, there by that break the free radical chain reaction, so that polyphenolic rich extracts or fractions widely used in pharmaceutical, nutraceutical, medicinal and cosmetic application (Ali et al., 2018). Results of flavonoid and phenolic content shown in Table 3 and Figure 1.

\section{Identification of flavonoids in the butanol column fractions}

Among 40 subfraction of butanol fraction from in the column chromatography $18,20,21,22$ subfraction showed same spot as that of standard flavonoid quercetin on TLC. From observation we came to know that butanol extract contains flavonoid type compounds (Gwatidzo et al., 2018). Considering of butanol fraction for in vivo cardioprotective activity than other fractions was well supported with its TLC data. TLC spots of flavonoid shown in Figure 2.

\section{Effect of butanol fractions of R. ornata on morphological changes}

B.W among all groups of animals were not changed significantly but weight of heart, ratio of heart weight (H.W) and B.W were observed as significant $(* * p<0.051)$ increase in ISO injected rats. Whereas butanol fraction of $R$. ornata dose dependently retain normal H.W/B.W ratio $(* p<0.05$ at 200 $\mathrm{mg} / \mathrm{kg} \mathrm{b}$. wt, $* * p<0.01$ at $400 \mathrm{mg} / \mathrm{kg} \mathrm{b}$. wt) compared to ISO injected rats. As increase in H.W/B.W ratio in ISO injected animals indicating the hypertrophy as well as inflammation. Pretreatment with butanol fraction of $R$. ornata reversed the morphological changes resulting in reduced hypertrophy and weight. It is supported with previous literature that flavonoids rich products reduced ISO induced deposition of collagen and inflammation, is the cause of cardiac hypertrophy (Karthikeyan et al., 2007). Table 4 gives the details of B.W changes.

\section{Effect of butanol fractions of R. ornata on ISO induced ECG patterns}

Significant $(* * * p<0.001)$ abnormal ECG patterns such as ST segment elevation and weaking of R- wave was seen with ISO injection. These patterns were efficiently improved by butanol fraction at $400 \mathrm{mg} / \mathrm{kg}(* p<0.05, * * p<0.01)$ than lower dose $(200 \mathrm{mg} / \mathrm{kg})$. Abnormal ECG patterns such 

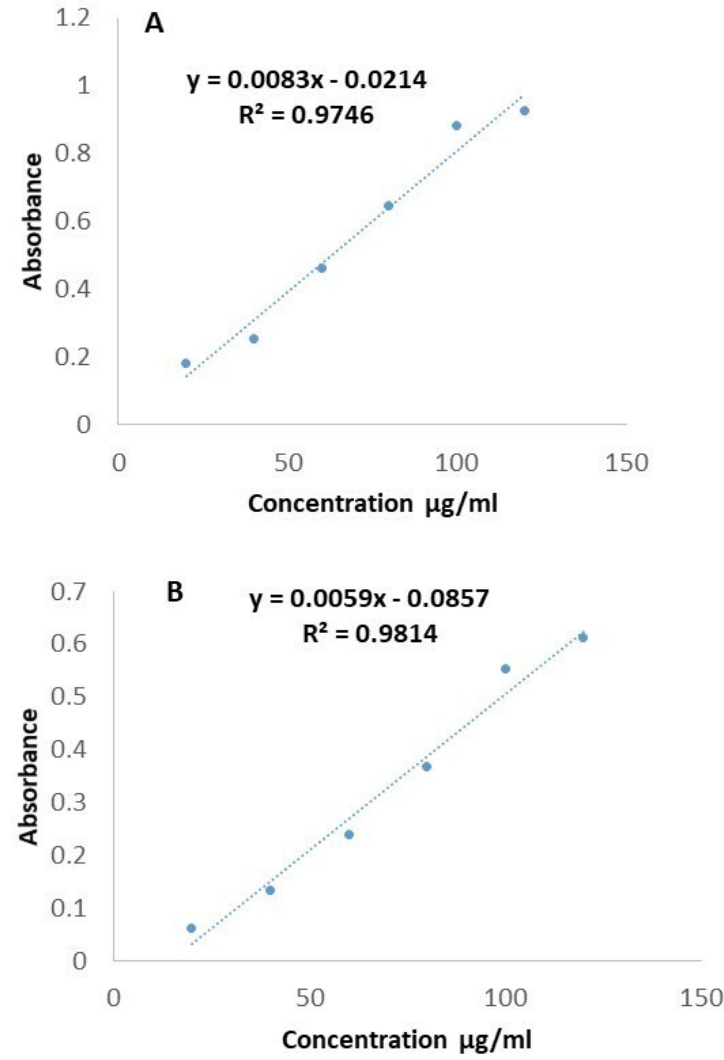

Figure 1. Regression line of gallic acid and quercetin.

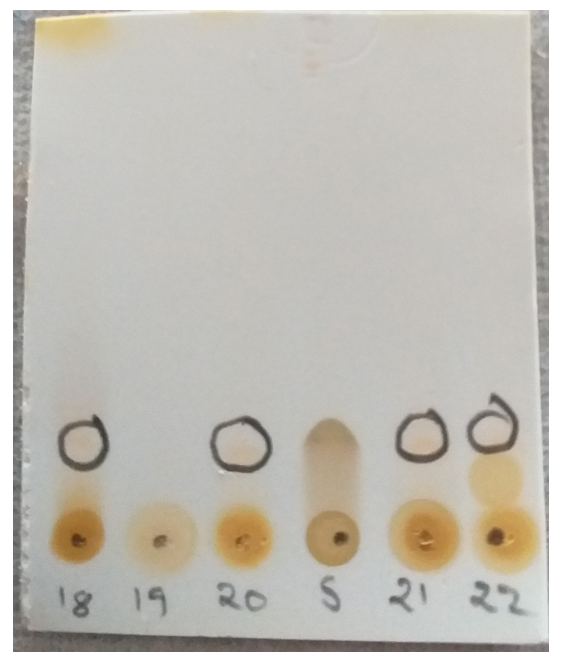

Figure 2. TLC Identification of flavonoids in the butanol fraction.

as ST segment elevation, weaking of $\mathrm{R}$ wave are the key to diagnosing myocardial infraction. These changes are replicated in rats given with ISO injection, are associated with transmural ischemia caused by cardiac over activity, coronary ischemia and oxidative damage (Upaganlawar et al., 2012). Pathological ECG changes were comparatively alleviated in the rats treated with polyphenol rich fraction. ECG findings are shown in Figures 3 and 4.

\section{Effect of butanol fractions of $\boldsymbol{R}$. ornata on serum biochemical parameters}

MI indicators include CK-MB, LDH and C-RP are elevated $(* * * p<0.001)$ in the ISO injected rats compared to normal rats. Butanol fraction treated rats observed as significant reduction $\left(\mathrm{CK}-\mathrm{MB}-{ }^{*} p<0.01, \mathrm{LDH}-* p<0.05\right.$ and $\mathrm{C}-\mathrm{RP}-* p$ $<0.05$ ) its levels in the serum especially at $400 \mathrm{mg} / \mathrm{kg}$ treated rats. Autooxidation of ISO and free radical formation would have destabilized the membrane myocytes which leads to leakage of $\mathrm{LDH}$ and CK-MB and also enhances serum levels of inflammatory marker (C-RP). It was observed that administration of polyphenol rich butanol fraction showed significant reduction in $\mathrm{LDH}, \mathrm{CK}$ $\mathrm{MB}$ and C-RP. This endorses its protective against ISO induced cardiac ischemia. (Govindasami et al., 2020). Results were shown in Table 5.

\section{Effect of butanol fractions of $\boldsymbol{R}$. ornata on cardiac tissue antioxidant parameters}

Myocardial tissue levels of SOD, CAT, GSH and total proteins were significantly $(* * * p<0.001)$ decreased but MDA levels increased $(* * * p<0.001)$ in the ISO injected group compared with normal rats. SOD $(* * * p<0.001)$, CAT $(* p<$ $0.05)$, GSH $(* * * p<0.001)$, total proteins $(* * p<0.01)$ were increased and MDA $(* * * p<0.001)$ was decreased by butanol fraction (especially at $400 \mathrm{mg} / \mathrm{kg}$ ) compared with ISO treated rats. The degree of oxidative stress induced cardiac damage is dependents on close balance between defensive factor of oxidative stress such as SOD, CAT, GSH and cytotoxic free radicals (Mnafgui et al., 2016). Quinone metabolites of ISO are highly toxic, highly reactive interact with oxygen causes generation of superoxide ion, $\mathrm{H}_{2} \mathrm{O}_{2}$ and further generate highly reactive hydroxyl radicle are known to cause severe oxidative stress in myocardium (Hemalatha et al., 2016). Excessive formation of free radicals causes myocardial phospholipid peroxidation which in turn prone for cellular injury and is determined by elevation of malondialdehyde content in heart tissue of ISO group (Rathore et al., 2000). These pathological changes are significantly decreased by butanol fractions of $R$. ornata (200 and $400 \mathrm{mg} / \mathrm{kg}$ b.w orally) treatment when compared to ISO group. These effects are mainly due to its antioxidant rich flavonoids. Reduced glutathione protects the $\mathrm{SH}$ groups of tissue proteins from cytotoxic free radical or from lipid peroxides. Overconsumption of reduced glutathione or deficiency of reduced glutathione may be the cause of damaged myocardium by ISO administered rats (Sudha et al., 2013). Treatment with butanol fraction of $R$. ornata at 400 $\mathrm{mg} / \mathrm{kg}$ was efficiently balanced reduced glutathione content, it indicates antioxidant property of the extract. Reduction of mutually defensive antioxidant proteins such as SOD and CAT is demonstrated in ISO injected rats. Overwhelming production of free radicals (super oxide and hydrogen peroxide radicals) from auto-oxidation of ISO, makes the antioxidant proteins deficiency state. Increased levels of SOD and CAT with butanol fraction of $R$. ornata (200 and $400 \mathrm{mg} / \mathrm{kg}$ ) might be it allowed the tissue to synthesis the new defensive enzyme system while it neutralize the superoxide anion, hydroxyl radicle and $\mathrm{H}_{2} \mathrm{O}_{2}$ 
Table 4. Influence of butanol fraction of R. ornata on B.W, H.W and its ratio.

\begin{tabular}{|c|c|c|c|c|c|}
\hline & Normal & ISO control & $\begin{array}{c}\text { ISO+ carvedilol } \\
(2 \mathrm{mg} / \mathrm{kg} / \text { day, p.o. })\end{array}$ & $\begin{array}{c}\text { ISO + Butanol fraction of } \\
\text { R. ornata }(200 \mathrm{mg} / \mathrm{kg} / \mathrm{day}, \text { p.o. })\end{array}$ & $\begin{array}{c}\text { ISO + Butanol fraction of } \\
\text { R. ornata }(400 \mathrm{mg} / \mathrm{kg} / \mathrm{day}, \text { p.o. })\end{array}$ \\
\hline B.W (g) & $216 \pm 9.45$ & $222 \pm 7.26$ & $212 \pm 10.1$ & $213 \pm 20.3$ & $225 \pm 14.7$ \\
\hline H.W (g) & $0.810 \pm 0.0321$ & $1.26 \pm 0.0404^{* * *}$ & $0.843 \pm 0.102^{* *}$ & $0.953 \pm 0.0318^{*}$ & $0.907 \pm 0.0240^{* *}$ \\
\hline $\mathrm{HW} / \mathrm{BW}$ ratio & $0.375 \pm 0.00996$ & $0.557 \pm 0.0403^{* *}$ & $0.404 \pm 0.0646^{* *}$ & $0.457 \pm 0.0547^{*}$ & $0.406 \pm 0.0246^{* *}$ \\
\hline
\end{tabular}

Represented mean \pm SEM values $(n=6)$ considered as significant when $p$ values less than 0.05 and all groups were compared with ISO control group.

$P$ values are marked as follows i.e., ${ }^{*} p<0.05 ;{ }^{* *} p<0.01 ; * * *<0.001$.
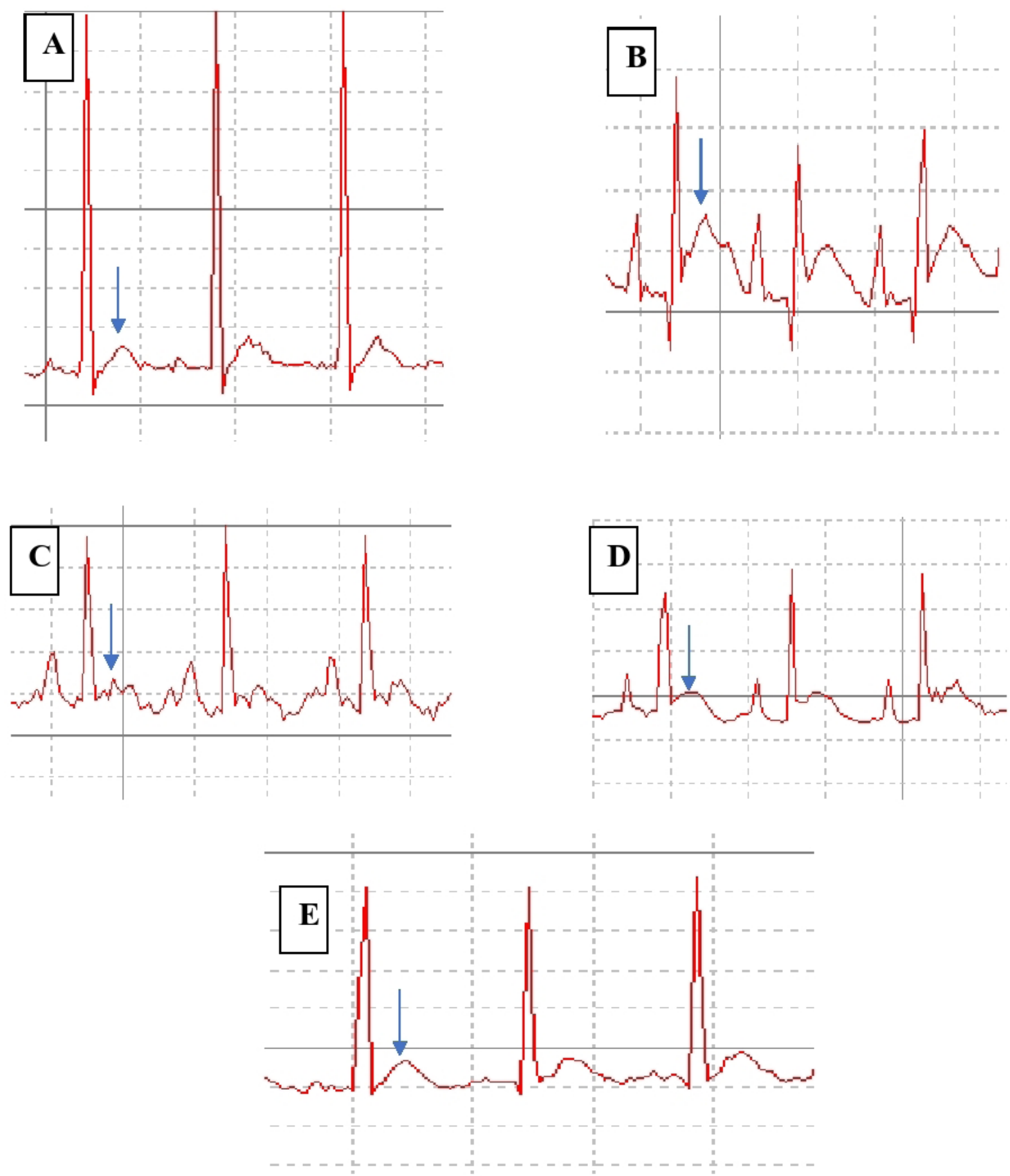

Figure 3. Representation of ECG changes (A) Normal control (B) ISO control (C) Carvedilol treated group (D). Butanol fractions of $R$. ornata 200 $\mathrm{mg} / \mathrm{kg}$ Pre-treated Group E. Butanol fractions of $R$. ornata $400 \mathrm{mg} / \mathrm{kg}$ Pre-treated group. 

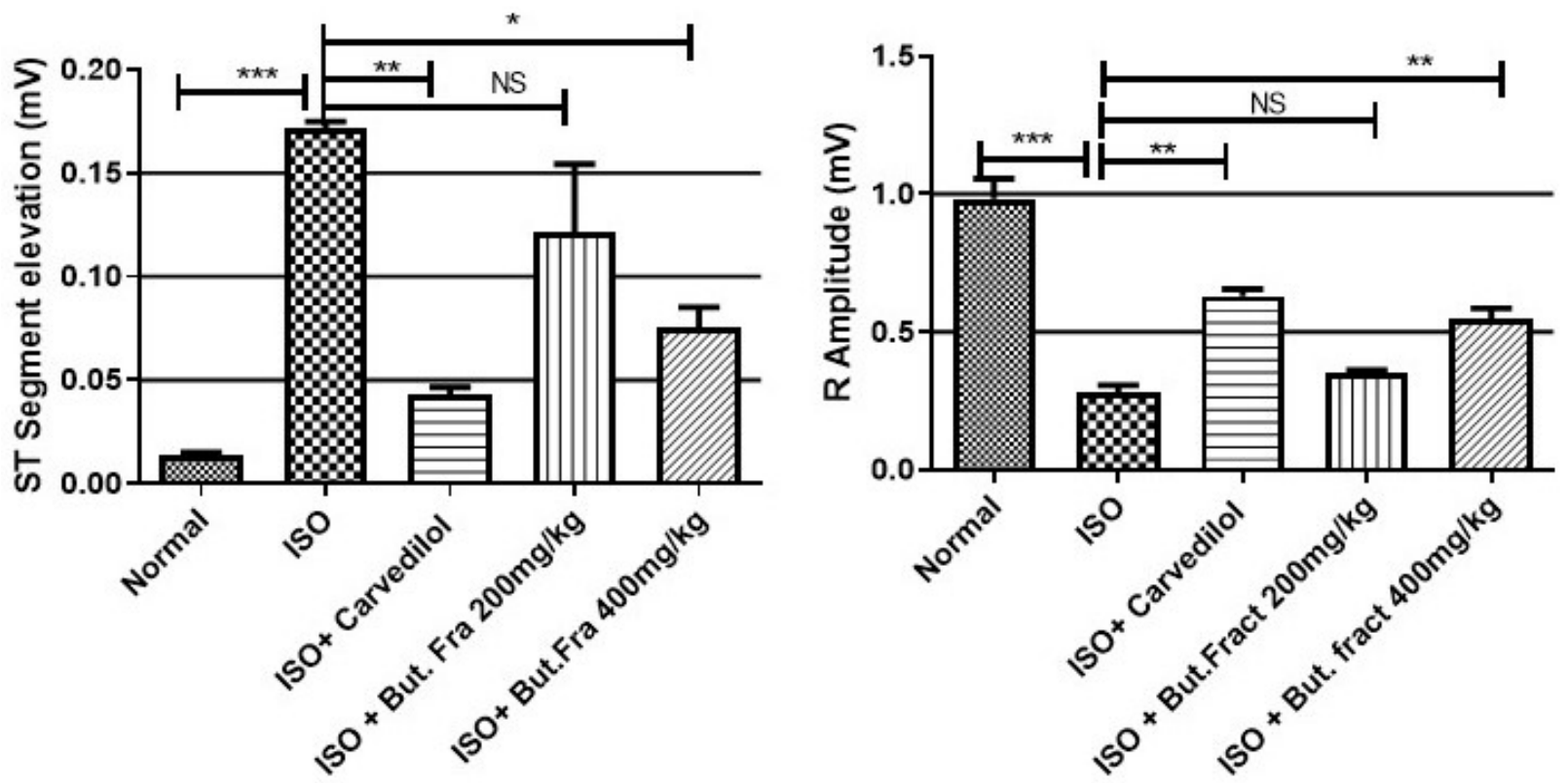

Figure 4. ST segment \& R-Amplitude changes in ECG. Represented mean \pm SEM values $(n=6)$ considered as significant when $p$ values less than 0.05 and all groups were compared with ISO control group. $p$ values are marked as follows i.e., ${ }^{*} p<0.05 ; * * p<0.01 ; * * * p<0.001$.

Table 5. Effect of butanol fractions of R. ornata serum cardiac markers.

\begin{tabular}{|c|c|c|c|c|c|}
\hline & Normal & ISO & $\begin{array}{c}\text { ISO+ carvedilol } \\
(2 \mathrm{mg} / \mathrm{kg} / \text { day, p.o. })\end{array}$ & $\begin{array}{c}\text { ISO + Butanol fraction of } \\
\text { R. ornata }(200 \mathrm{mg} / \mathrm{kg} / \mathrm{day} \text {, p.o. })\end{array}$ & $\begin{array}{c}\text { ISO + Butanol fraction of } \\
\text { R. ornata }(400 \mathrm{mg} / \mathrm{kg} / \mathrm{day}, \text { p.o. })\end{array}$ \\
\hline $\begin{array}{l}\text { CK-MB } \\
(\mathrm{IU} / 1)\end{array}$ & $52.5 \pm 3.36$ & $135 \pm 4.74 * * *$ & $91.5 \pm 9.48^{* * *}$ & $119 \pm 5.11^{\mathrm{NS}}$ & $98.3 \pm 2.55^{* *}$ \\
\hline LDH (IU/l) & $59.0 \pm 0.964$ & $177 \pm 7.27^{* * *}$ & $120 \pm 7.52^{* * *}$ & $147 \pm 9.92^{\mathrm{NS}}$ & $135 \pm 7.50^{*}$ \\
\hline C-RP & $1.85 \pm 0.344$ & $7.36 \pm 0.578 * * *$ & $3.82 \pm 0.295^{* *}$ & $6.16 \pm 0.672^{\mathrm{NS}}$ & $4.69 \pm 0.346^{*}$ \\
\hline
\end{tabular}

Represented mean \pm SEM values $(n=6)$ considered as significant when $p$ values less than 0.05 and all groups were compared with ISO control group. $p$ values are marked as follows i.e., ${ }^{*} p<0.05 ; * * p<0.01 ; * * * p<0.001$

Table 6. Effect of butanol fractions of $R$. ornata of cardiac antioxidants and lipid peroxidation.

\begin{tabular}{|c|c|c|c|c|c|}
\hline Group & SOD & CAT & GSH & MDA & Total protein \\
\hline Normal & $16.7 \pm 0.537$ & $11.2 \pm 0.506$ & $6.23 \pm 0.413$ & $1.46 \pm 0.068$ & $8.95 \pm 1.15$ \\
\hline ISO control & $6.98 \pm 0.418^{* * * *}$ & $3.35 \pm 0.328^{* * *}$ & $2.42 \pm 0.447^{* * * *}$ & $3.75 \pm 0.239^{* * *}$ & $2.95 \pm 0.23^{* * *}$ \\
\hline Carvedilol (2 mg/kg/day, p.o.) & $14.3 \pm 0.630^{* * *}$ & $7.72 \pm 0.355^{* * *}$ & $5.42 \pm 0.336^{* * *}$ & $2.20 \pm 0.207^{* * * *}$ & $7.91 \pm 0.77^{* *}$ \\
\hline Butanol fraction of $R$. ornate $(200 \mathrm{mg} / \mathrm{kg} /$ day, p.o. $)$ & $10.4 \pm 0.514^{* *}$ & $3.61 \pm 0.377^{\mathrm{ns}}$ & $4.57 \pm 0.223^{* *}$ & $2.72 \pm 0.269^{* *}$ & $6.36 \pm 0.68^{*}$ \\
\hline Butanol fraction of $R$. ornata $(400 \mathrm{mg} / \mathrm{kg} /$ day, p.o. $)$ & $12.4 \pm 0.563^{* * * *}$ & $5.39 \pm 0.425^{*}$ & $5.19 \pm 0.285^{* * *}$ & $2.133 \pm 0.137^{* * * *}$ & $7.45 \pm 0.55^{* *}$ \\
\hline
\end{tabular}

Represented mean \pm SEM values $(n=6)$ considered as significant when $p$ values less than 0.05 and all groups were compared with ISO control group. $p$ values are marked as follows i.e., $* p<0.05 ; * p<0.01 ; * * * p<0.001$.

molecules (Priscilla and Prince, 2009). Antioxidant parameters results were observed in Table 6.

\section{Effect of butanol fractions of $\boldsymbol{R}$. ornata on inflamation markers in cardiac tissue.}

Cardiac tissue inflammation markers such as TNF- $\alpha$ and IL-6 increased significantly $(* * * p<0.001)$ and IL-10 (antiinflammatory protein) decreased significantly $(* * * p<0.001)$ in ISO injected rats. Butanol fraction treatment attenuates the increase of TNF- $\alpha(* p<0.05)$, IL-6 $(* * p<0.01)$, and enhance the levels of IL-10 $(* p<0.05)$ at $400 \mathrm{mg} / \mathrm{kg}$ efficiently compared with ISO injected rats. Several studies have shown that imbalance of deleterious inflammatory molecules (IL-6 and TNF- $\alpha$ ) and protective molecules (IL-10) can occur immediately after myocardial damages, especially observed in oxidative stress condition, has significant role in impairment of myocardial contractility. Therefore, establishment of balance between inflammatory cytokines is considered as valuable option to preserve the heart function in myocardial damage. We observed increase in inflammation of cardiac tissue in ISO injected rats as is indicated by higher amount of IL- 6 , TNF- $\alpha$ \& less amount of IL-10, which is also observed in the similar experiments. 
Polyphenolic rich butanol fraction significantly decreased inflammatory cytokine such as IL-6, TNF- $\alpha$ \& increased in IL-10 in cardiac tissue. Anti-inflammatory property of butanol fraction may have cardio protection (Raish et al., 2019). Inflammatory markers changes were observed in Figure 5.

\section{Effect of butanol fractions of $\boldsymbol{R}$. ornata on cardiac ATPases and associated electrolyte changes}

The cardiac membrane bound ATPases such as $\mathrm{Na}^{+} \mathrm{K}^{+}$ ATPase, $\mathrm{Ca}^{2+}$ ATPase are significantly $(* * * p<0.001)$ decreased in ISO administered rats compared with control animals whereas their activities were regained significantly $(* * p<0.01)$ by butanol fraction treatment. Along with, cardiac content of sodium, calcium is increased and potassium decreased significantly $(* * * p<0.001)$ in ISO administered rats as that of control rats. Butanol fraction at $400 \mathrm{mg} / \mathrm{kg}$ correct the imbalance of sodium $(* * p<0.01)$, calcium $(* * * p<0.001)$ and potassium $(* * p<0.01)$ caused by ISO. At molecular level ISO induced cardiac membrane damage was assessed by measuring cardiac ATPases. These are involved in pumping of selective ions across the cardiac membrane to maintain the ionic balance state so that cardiac cell undergoes sequential contraction and relaxation. At high dose, ISO induced free radicals attack the sensitive thiol segment of ATPases which decreases the functional capacity of membrane bound enzymes and triggers accumulation of intracellular sodium and calcium. These changes were observed in our experiment as indicated by lesser activity of sodium, potassium and calcium ATPases and greater intracellular sodium, calcium and lesser potassium levels. Polyphenolic rich butanol fraction administration was significantly regaining the activity of $\mathrm{Na}^{+} \mathrm{K}^{+}$ATPase, $\mathrm{Ca}^{2+}$ ATPase as well as normalization of intracellular ionic balance, this might be due to antioxidant activity protect the thiol groups of membrane bound enzymes from oxidative stress. These observations were matched with earlier reports. (Shaik et al., 2020). Membrane bound enzymes changes in treated groups are shown in Table 7 and Figure 6.

\section{Histopathology}

The Histologically ISO induced myocardial infraction has been observed as severe alteration of myocyte shape, focal fibrosis and loss of integrity of myocyte, necrotic changes. Theses pathological alteration were efficiently normalized by pretreatment of butanol fraction of $R$. ornata, is indicate its protective effect on pathological changes associated with oxidative stress (Cetin, 2019). Histopathological changes in different groups are shown in Figure 7.
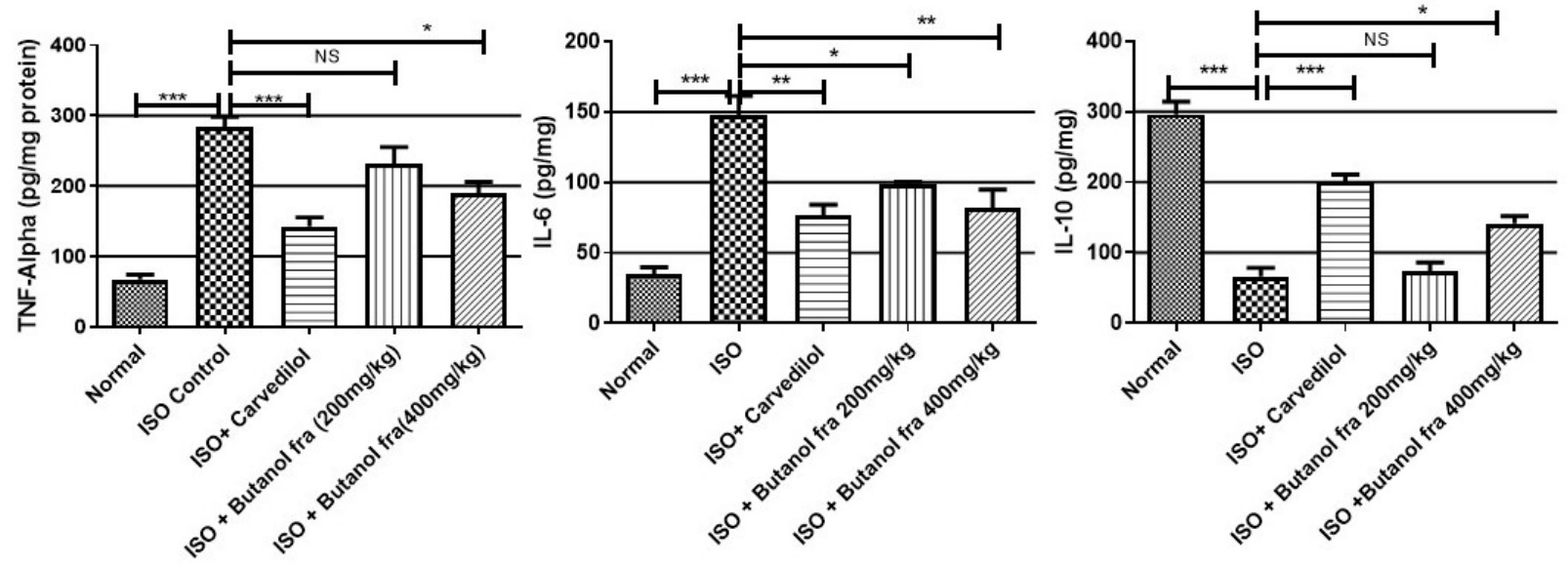

Figure 5. Effect of butanol fractions of $R$. ornata on inflammatory cytokines. Represented mean \pm SEM values $(n=6)$ considered as significant when $p$ values less than 0.05 and all groups were compared with ISO control group. $p$ values are marked as follows i.e., ${ }^{*} p<0.05 ; * * p<0.01$; $* * * p<0.001$.

Table 7. Effect of butanol fractions of R. ornata of membrane bound ATP ases on cardiac tissue.

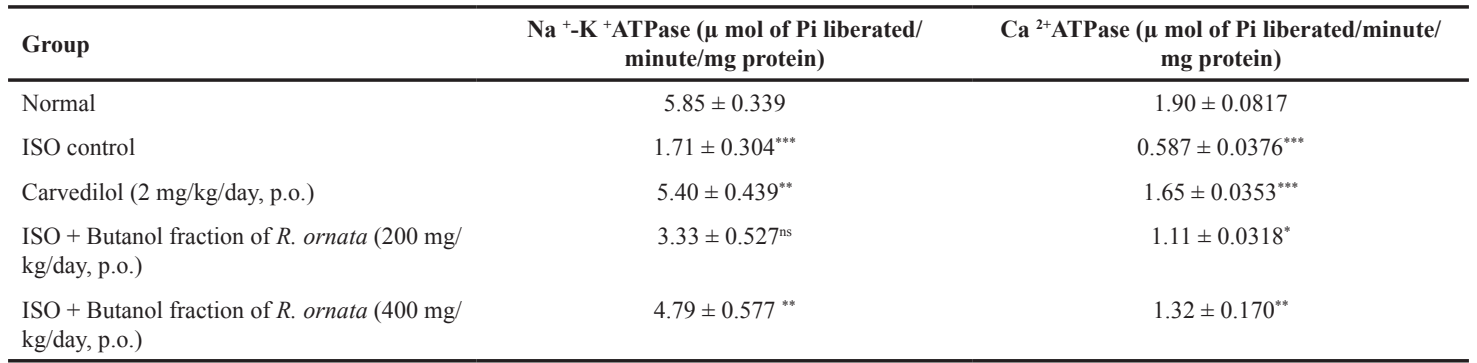

Represented mean \pm SEM values $(n=6)$ considered as significant when $p$ values less than 0.05 and all groups were compared with ISO control group. $P$ values are marked as follows i.e., $* p<0.05 ; * * p<0.01 ; * * p<0.001$. 

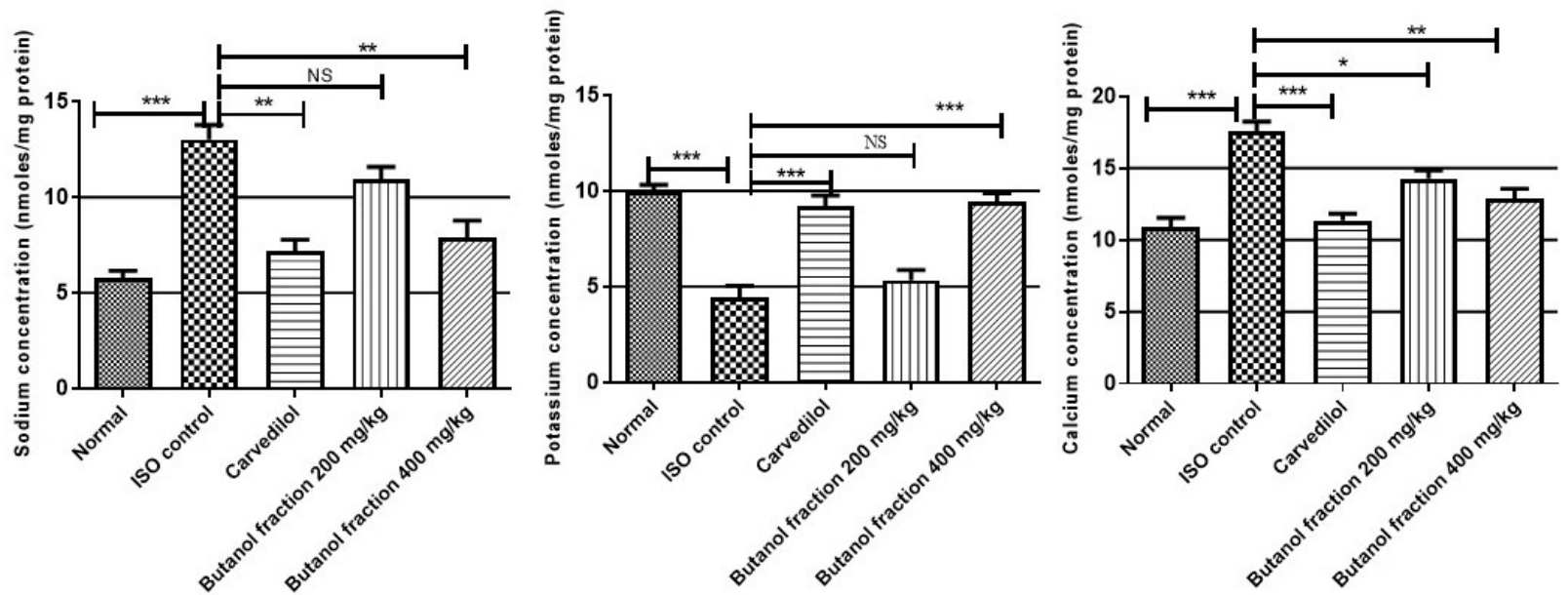

Figure 6. Effect of butanol fraction on cardiac tissue mineral ions concertation. Represented mean \pm SEM values $(n=6)$ considered as significant when $p$ values less than 0.05 and all groups were compared with ISO control group. $p$ values are marked as follows i.e., ${ }^{*} p<0.05 ;{ }^{*} p<0.01$; $* * * p<0.001$.
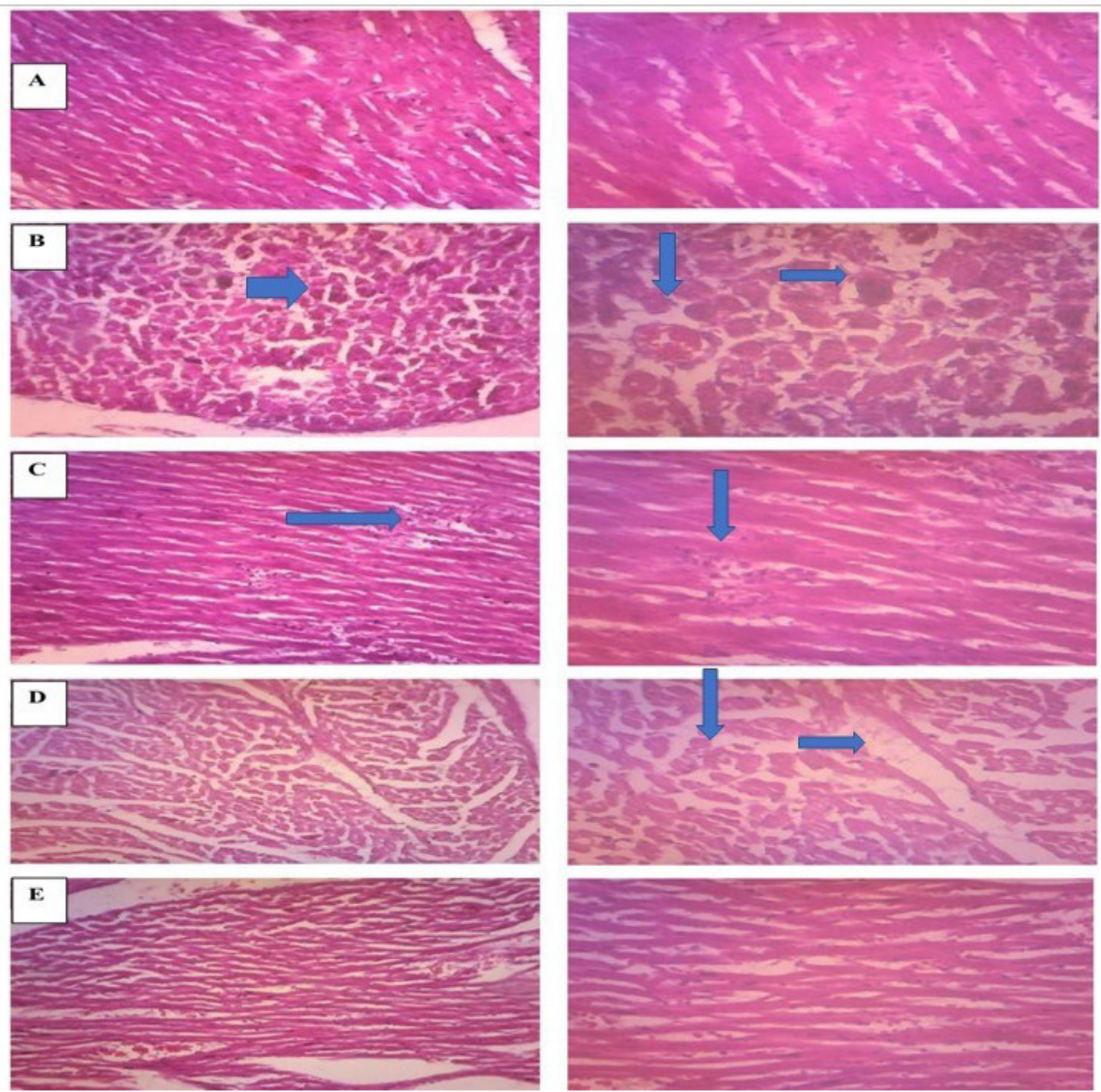

Figure 7. Representation of histopathological changes in (A) Normal control (B) ISO (C) Carvedilol (2 mg/kg) (D) Butanol fractions of $R$. ornata $200 \mathrm{mg} . \mathrm{kg}$ (E) Butanol fractions of $R$. ornata $400 \mathrm{mg} . \mathrm{kg}$. 


\section{CONCLUSION}

The present experiment work explored the protective effect of butanol fraction of $R$. ornata from results of in vivo experiment. Molecular basis of its protection due to its high phenolic and flavonoid content protect the myocardium especially at $400 \mathrm{mg} / \mathrm{kg}$ from oxidative stress as result of antioxidant, retention of cell viability, membrane stabilization, anti-inflammatory effect and functional stabilization of membrane bound ATPase. Hence, $R$. ornata may be considered as a cardioprotective agent in further studies, in order to warrant its protective effect on heart.

\section{LIST OF ABBREVIATIONS}

B.W: Body weight; $\mathrm{Ca}^{2+}$ ATPase: Calcium adenosine triphosphatase; CAT: Catalase; CK-MB: Creatine kinase-MB; CPCSEA: Committee for the Purpose of Control And Supervision of Experiments on Animals; C-RP: C-reactive protein; DTNB: 5,5 dithiobis 2- nitro benzoic acid; ECG: Electrocardiogram; EDTA: Ethylenediaminetetraacetic acid; GSH: Reduced glutathione; H.W: Heart weight; IL: Interleukins; ISO: Isoproterenol; LDH: Lactate dehydrogenase; MDA: Malondialdehyde ; MI: Myocardial infarction; $\mathrm{Na}^{+} \mathrm{K}^{+}$ATPase : Sodium-potassium adenosine triphosphatase; SOD: Superoxide dismutase; TBA: Thiobarbituric acid; TCA: Trichloroacetic acid ; TLC: Thin Layer Chromatography; TNF- $\alpha$ : Tumour Necrosis Factor alpha.

\section{ACKNOWLEDGMENTS}

Authors are thankful to the Principal, Correspondent for their constant support, encouragement and DST-FIST Facility of Raghavendra Institute of Pharmaceutical Education and Research, Anantapur, AP, India for the providing the proper facility to carry out this work.

\section{AUTHOR CONTRIBUTIONS}

All authors made substantial contributions to conception and design, acquisition of data, or analysis and interpretation of data; took part in drafting the article or revising it critically for important intellectual content; agreed to submit to the current journal; gave final approval of the version to be published; and agree to be accountable for all aspects of the work. All the authors are eligible to be an author as per the international committee of medical journal editors (ICMJE) requirements/guidelines.

\section{FUNDING}

There is no funding to report.

\section{CONFLICTS OF INTEREST}

The authors report no financial or any other conflicts of interest in this work.

\section{ETHICAL APPROVALS}

The IAEC of RIPER, Anantapur has approved the research protocol [878/ac/05/Committee for the Purpose of Control And Supervision of Experiments on Animals (CPCSEA)/005/2016] as per guidelines of CPCSEA, Govt of India, New Delhi.

\section{PUBLISHER'S NOTE}

This journal remains neutral with regard to jurisdictional claims in published institutional affiliation.

\section{REFERENCES}

Adenipekun K, Omóbòwálé T, Oyagbemi A, Adedapo A, Ashafa A, Yakubu M, Adejumobi O, Ola-Davies O, Ajibade T. Butanol extract of Morinda Lucida (BEML) protects against Isoproterenol-induced myocardial infarction in Wistar rats. FASEB J, 2018; 32(S1):lb298.

Aebi H. Catalase in vivo. Methods Enzymol, 1984; 105:121-6. Al-Numair KS, Veeramani C, Alsaif MA, Chandramohan G. Influence of kaempferol, a flavonoid compound, on membrane-bound ATPases in streptozotocin-induced diabetic rats. Pharm Biol, 2015; 53(9):1372-8.

Ali S, Khan MR, Sajid M, Zahra Z. Phytochemical investigation and antimicrobial appraisal of Parrotiopsis jacquemontiana (Decne) Rehder. BMC Complement Altern Med, 2018; 18(1):43.

Al-Numair KS, Veeramani C, Alsaif MA, Chandramohan G. Influence of kaempferol, a flavonoid compound, on membranebound ATPases in streptozotocin-induced diabetic rats. Pharm Biol. 2015;53(9):1372-8.

Aronow WS. Epidemiology, pathophysiology, prognosis, and treatment of systolic and diastolic heart failure. Cardiol Rev, 2006; 14(3):108-24.

Auwal MS, Saka S, Mairiga IA, Sanda KA, Shuaibu A, Ibrahim A. Preliminary phytochemical and elemental analysis of aqueous and fractionated pod extracts of Acacia nilotica (Thorn mimosa). Vet Res Forum, 2014; 5(2):95-100.

Brewer MS. Natural antioxidants: sources, compounds, mechanisms of action, and potential applications. Compr Rev Food Sci Food Saf, 2011; 10(4):221-47.

Çetin E. Pretreatment with $\beta$-glucan attenuates isoprenalineinduced myocardial injury in rats. Exp Physiol, 2019; 104(4):505-13.

Cory H, Passarelli S, Szeto J, Tamez M, Mattei J. The role of polyphenols in human health and food systems: a mini-review. Front Nutr, 2018; $21 ; 5: 87$.

Etame RM, Mouokeu RS, Poundeu FS, Voukeng IK, Cidjeu CL, Tiabou AT, Yaya AJ, Ngane RA, Kuiate JR, Etoa FX. Effect of fractioning on antibacterial activity of $\mathrm{n}$-butanol fraction from Enantia chlorantha stem bark methanol extract. BMC Complement Altern Med, 2019; 19(1):56.

Ganapathy R, Ramachandran A, Shivalingaiah SB, Bishir M, Bhojaraj S, Sridhar S, Mohan SK, Veeraraghavan VP, Chidambaram SB, Essa MM, Qoronfleh MW. Cardioprotective potential of polyphenols rich thraatchathi chooranam against isoproterenol induced myocardial necrosis in experimental rats. BMC Complement Med Ther, 2020; 20(1):1-2.

Govindasami S, Uddandrao VV, Raveendran N, Sasikumar $\mathrm{V}$. Therapeutic potential of biochanin-A against isoproterenol-induced myocardial infarction in rats. Cardiovasc Hematol Agents Med Chem, 2020; 18(1):31-6.

Gwatidzo L, Dzomba P, Mangena M. TLC separation and antioxidant activity of flavonoids from Carissa bispinosa, Ficus sycomorus, and Grewia bicolar fruits. Nutrire, 2018; 43(1):3.

Hemalatha KL, Prince PS. Preventive effects of zingerone on cardiac mitochondrial oxidative stress, calcium ion overload and adenosine triphosphate depletion in isoproterenol induced myocardial infarcted rats RSC Adv, 2016; 6(113):112332-9.

Karthikeyan K, Bai BS, Devaraj SN. Cardioprotective effect of grape seed proanthocyanidins on isoproterenol-induced myocardial injury in rats. Int J Cardiol, 2007; 115(3):326-33.

Kirtikar KR, Basu BD. Indian medicinal plants. Dehradun: International Book Distributors, 1918.

Li Y, Feng J, Mo Y, Liu H, Yang B. Concordance between cardioprotective effect on isoproterenol-induced acute myocardial ischemia and phenolic content of different extracts of Curcuma aromatica. Pharm Biol, 2016; 54(12):3226-31.

Lowry OH, Rosebrough NJ, Farr AL, Randall RJ. Protein measurement with the folin phenol reagent. J Biol Chem, 1951; 193:265-75.

Maithili V, Dhanabal SP, Mahendran S, Vadivelan R. Antidiabetic activity of ethanolic extract of tubers of Dioscorea alata in alloxan induced diabetic rats. Indian J Pharmacol, 2011; 43(4):455. 
Manjunatha S, Shaik AH, Al Omar SY, Mohammad A, Kodidhela LD. Combined cardio-protective ability of syringic acid and resveratrol against isoproterenol induced cardio-toxicity in rats via attenuating NF-kB and TNF- $\alpha$ pathways. Sci Rep, 2020; 10(1):1-3.

Misra HP, Fridovich I. The role of superoxide anion in the autoxidation of epinephrine and a simple assay for superoxide dismutase. $\mathrm{J}$ Biol Chem, 1972; 247(10):3170-5.

Mnafgui K, Hajji R, Derbali F, Gammoudi A, Khabbabi G, Ellefi H, Allouche N, Kadri A, Gharsallah N. Anti-inflammatory, antithrombotic and cardiac remodeling preventive effects of eugenol in isoproterenolinduced myocardial infarction in Wistar rat. Cardiovasc Toxicol, 2016; 16(4):336-44.

Mohan M, Patankar P, Ghadi P, Kasture S. Cardioprotective potential of punica granatum extract in isoproterenol-induced myocardial infarction in Wistar rats. J Pharmacol Pharmacother, 2010; 1(1):32.

Mondal M, Hossain MS, Das N, Khalipha AB, Sarkar AP, Islam MT, Smrity SZ, Biswas S, Kundu SK. Phytochemical screening and evaluation of pharmacological activity of leaf methanolic extract of Colocasia affinis Schott. Clin Phytoscience, 2019; 5(1):8.

Moron MS, Depierre JW, Mannervik B. Levels of glutathione, glutathione reductase and glutathione S-transferase activities in rat lung and liver. Biochim Biophys Acta, 1979; 582(1):67-78.

Panda S. Butanolic fraction of Moringa oleifera Lam. (Moringaceae) attenuates isoproterenol-induced cardiac necrosis and oxidative stress in rats: an EPR study. EXCLI J, 2015; 14:64.

Parasuraman S, Raveendran R, Kesavan R. Blood sample collection in small laboratory animals. J Pharmacol Pharmacother, 2010; $1(2): 87$.

Patel V, Upaganlawar A, Zalawadia R, Balaraman R. Cardioprotective effect of melatonin against isoproterenol induced myocardial infarction in rats: a biochemical, electrocardiographic and histoarchitectural evaluation. Eur J Pharmacol, 2010; 644(1-3):160-8.

Priscilla DH, Prince PS. Cardioprotective effect of gallic acid on cardiac troponin- $\mathrm{T}$, cardiac marker enzymes, lipid peroxidation products and antioxidants in experimentally induced myocardial infarction in Wistar rats. Chem Biol Interact, 2009; 179(2-3):118-24.

Raish M, Ahmad A, Ansari MA, Alkharfy KM, Ahad A, Khan A, Ali N, Ganaie MA, Hamidaddin MA. Beetroot juice alleviates isoproterenolinduced myocardial damage by reducing oxidative stress, inflammation, and apoptosis in rats. 3 Biotech. 2019; 9(4):147.

Rathore N, Kale M, John S, Bhatnagar D. Lipid peroxidation and antioxidant enzymes in isoproterenol induced oxidative stress in rat erythrocytes. Indian J Physiol Pharmacol, 2000; 44(2):161-6.

Rita WS, Swantara IM, Asih IR, Sinarsih NK, Suteja IK. Total flavonoid and phenolic contents of n-butanol extract of Samanea saman leaf and the antibacterial activity towards Escherichia coli and Staphylococcus aureus. AIP Conf Proc, 2016; 1718(1):060005.

Saeed N, Khan MR, Shabbir M. Antioxidant activity, total phenolic and total flavonoid contents of whole plant extracts Torilis leptophylla L. BMC Complement Altern Med, 2012; 12(1):221.

Senguttuvan J, Paulsamy S, Karthika K. Phytochemical analysis and evaluation of leaf and root parts of the medicinal herb, Hypochaeris radicata L. for in vitro antioxidant activities. Asian Pac J Trop Biomed, 2014; 4:S359-67.

Shahzad S, Mateen S, Mariyath PM, Naeem SS, Akhtar K, Rizvi W, Moin S. Protective effect of syringaldehyde on biomolecular oxidation, inflammation and histopathological alterations in isoproterenol induced cardiotoxicity in rats. Biomed Pharmacother. 2018; 108:625-33.

Shahzad S, Mateen S, Naeem SS, Akhtar K, Rizvi W, Moin S. Syringic acid protects from isoproterenol induced cardiotoxicity in rats. Eur J Pharmacol, 2019; 849:135-45.

Shaik AH, Mohammed AK, Sammeturi M, Al Omar SY, Mohammad A, Kodidhela LD. Maslinic acid ameliorate electrolytes, membrane bound ATPases, antioxidants and histopathology in isoprenaline attenuated myocardial toxicity in rats. J King Saud Univ Sci, 2020; 32(1):1055-9.

Shankar D, Patwardhan B. AYUSH for new India: vision and strategy. J Ayurveda Integr Med, 2017; 8(3):137.

Sharma V, Janmeda P. Extraction, isolation and identification of flavonoid from Euphorbia neriifolia leaves. Arab J Chem, 2017; 10(4): 509-14.

Slater TF, Sawyer BC. The stimulatory effects of carbon tetrachloride and other halogenoalkanes on peroxidative reactions in rat liver fractions in vitro. General features of the systems used. Biochem J, 1971; 123(5):805-14.

Speer H, D'Cunha NM, Alexopoulos NI, McKune AJ, Naumovski N. Anthocyanins and human health - a focus on oxidative stress, inflammation and disease. Antioxidants, 2020; 9(5):366.

Stalikas CD. Extraction, separation, and detection methods for phenolic acids and flavonoids. J Sep Sci, 2007; 30(18):3268-95.

Sudha M, Rajkumar D, Felix JW. Protective effect of glutathione against isoproterenol induced myocardial injury in rats. Indian J Physiol Pharmacol, 2013; 57(2):132-7.

Thomford NE, Senthebane DA, Rowe A, Munro D, Seele P, Maroyi A, Dzobo K. Natural products for drug discovery in the 21st century: innovations for novel drug discovery. Int J Mol Sci, 2018; 19(6):1578.

Upaganlawar A, Balaraman R. Cardioprotective effects of Lagenaria siceraria fruit juice on isoproterenol-induced myocardial infarction in wistar rats: a biochemical and histoarchitecture study. J Young Pharm, 2011; 3(4):297-303.

Upaganlawar A, Gandhi C, Balaraman R. Effect of green tea and vitamin $\mathrm{E}$ combination in isoproterenol induced myocardial infarction in rats. Plant Foods Hum Nutr, 2009; 64(1):75-80.

Upaganlawar A, Patel V, Balaraman R. Tomato lycopene attenuates myocardial infarction induced by isoproterenol electrocardiographic, biochemical and anti-apoptotic study. Asian Pac J Trop Biomed, 2012; 2(5):345-51.

Zhu C, Li W, Wang X, Xue J, Zhao L, Song Y, Zhou T, Zhang M. Phloroglucinol averts isoprenaline hydrochloride induced myocardial infarction in rats. Drug Dev Res, 2019; 80(4):453-60.

\section{How to cite this article:}

Sudheer A, Vijaya M, Devanna N. Functional role of polyphenol rich butanol fraction of Rivea ornata in experimentally induced myocardial infarction: Preservation of Cell viability and Free radical neutralization. J Appl Pharm Sci, 2021; 11(06):094-104. 